\title{
Aplikasi Berbagai Dosis dan Dua Jenis Guano pada Budidaya Tanaman Jagung Pakan (Zea mays. L) di Lahan Podsolik
}

\section{(Application of Various Doses And Two Kinds of Guano in Plant Cultivation Corn (Zea mays L.) in Podsolic Lands)}

\author{
M. Azai ${ }^{1)}$, Nur Hafizah ${ }^{2)}$ dan Mahdiannoor ${ }^{3)}$ \\ Program Studi Agroteknologi Sekolah Tinggi Ilmu Pertanian Amuntai \\ 1)azaysadewa@gmail.com \\ ${ }^{2)}$ Fifi_bjm@yahoo.co.id \\ ${ }^{3)}$ mahdi_186@yahoo.com
}

\begin{abstract}
ABSTRAK
Jagung pakan adalah salah satu pakan ternak yang memiliki banyak keunggulan, sebagai pakan jagung dimanfaatkan untuk sumber energi metabolis. Lahan podsolik merupakan lahan yang unsur haranya sangat rendah. Penelitian ini bertujuan untuk (i) mengetahui pengaruh interaksi berbagai dosis dan dua jenis guano, (ii) mengetahui pengaruh berbagai dosis guano, (iii) mengetahui pengaruh dua jenis guano, (iv) mendapatkan interaksi terbaik, (v) mendapatkan dosis terbaik, (vi) mendapatkan jenis guano terbaik pada budidaya tanaman jagung pakan di lahan podsolik. Penelitian ini dilakukan di Desa Hawang Kecamatan Limpasu Kabupaten Hulu Sungai Tengah dari bulan Maret sampai Juni 2018. Menggunakan Rancangan Acak Kelompok (RAK) Faktorial 2 faktor. Faktor pertama adalah berbagai dosis guano dengan 5 taraf : $d_{1}=1,5 \mathrm{~kg}$. petak ${ }^{-1}, d_{2}=3 \mathrm{~kg}$. petak ${ }^{-1}, d_{3}=4,5 \mathrm{~kg}$. petak ${ }^{-1}, d_{4}=6 \mathrm{~kg}$. petak ${ }^{-1}, d_{5}=7,5 \mathrm{~kg}$. petak ${ }^{-1} . \mathrm{Faktor}$ kedua adalah dua jenis guano dengan dua taraf : $g_{1}=$ guano kotoran kelelawar, $g_{2}=$ guano kotoran walet. Hasil penelitian menunjukkan bahwa interaksi antara berbagai dosis dan dua jenis guano tidak berpengaruh terhadap pertumbuhan dan hasil, kecuali berpengaruh sangat nyata terhadap panjang tongkol berkelobot, sedangkan faktor tunggal berbagai dosis berpengaruh nyata dan sangat nyata pada semua variabel pengamatan dan faktor dua jenis guano tidak berpengaruh pada semua variabel, kecuali berpengaruh nyata terhadap pertumbuhan tinggi tanaman pada umur 56 HST.
\end{abstract}

Kata kunci: Dosis, jenis, guano, tanaman jagung pakan, podsolik.

\section{ABSTRACT}

Corn feed is one animal feed that has many advantages, as corn feed is used for metabolic energy sources. Podsolic land is a land with very low nutrient value. This study aims to (i) determine the effect of various doses, and two types of guano interactions, (ii) determine the effect of various doses of guano, (iii) find out influence of two types of guano, (iv) get the best interaction, (v) get the best dose, (vi) get the best type of guano in the cultivation of corn feed in podsolic land. This research was conducted in Hawang Village, Limpasu District, Hulu Sungai Tengah Regency, from March to June 2018. They are using Group Random Design (GRD) Factorial 2 factors. The first factor is various doses of guano with five levels: $d_{1}=$ $1.5 \mathrm{~kg} . \mathrm{plot}^{-1}, d_{2}=3 \mathrm{~kg}$. plot ${ }^{-1}, d_{3}=4.5 \mathrm{~kg}$. plot ${ }^{-1}, d_{4}=6 \mathrm{~kg} . \mathrm{plot}^{-1}, d_{5}=7.5 \mathrm{~kg}$. plot $\mathrm{t}^{-1}$. The second factor is two types of guano with two levels: $g_{1}=$ bat guano, $g_{2}=$ swallow guano. The results showed that the interaction between various doses and two types of guano had no effect on growth and yield, except that the effect was very significant on long cob weighted, whereas a single factor of various doses had significant and very real effect on all observation variables and the factor of two types of guano had no effect on all variables. Except for significant effect on plant height growth at the age of 56 HST.

Keywords: Dosage, type, guano, feed corn plant, podsolik.

\section{PENDAHULUAN}

Data Direktorat Jenderal Hortikultura (2017), produksi jagung pakan ternak di Indonesia selama 5 tahun terakhir mengalami penurunan. Pada tahun 2011 produksi jagung pakan ternak sebesar 3.076.375 ton. Pada tahun 2012 mengalami penurunan, produksinya sebesar 1.537 .512 ton. Pada tahun 2013 mengalami kenaikan, produksinya sebesar 2.955 .840 ton. Pada tahun 2014 mengalami kenaikan, 
produksinya sebesar 3.164.061 ton dan tahun 2015 mengalami penurunan, produksinya sebesar 2.741.966 ton. Pada tahun 2016 produksi jagung pakan di Indonesia masih mengalami penurunan, produksinya hanya 884.679 ton. Menurut Zubachtirodin et., al. (2011), budidaya tanaman jagung di Indonesia masih rendah dikarenakan masih banyak petani yang membudidayakan tanaman jagung dengan cara tradisional, petani menanam dengan jarak tanam yang lebar dan tanah yang tidak subur seperti tanah podsolik, serta menggunakan pupuk yang tidak sesuai anjuran.

Tanah podsolik memiliki horizon organik di atas lapisan berpasir dan berwarna kabut pucat. Tanah berkembang dari bahan endapan misalnya pasir, lempung berpasir, batu pasir, atau tufa volkanik masam. Tanah ini dijumpai pada variasi iklim dan elevasi. Di Indonesia, tanah ini dijumpai pada ketinggian hingga 2000 meter dpl, dan curah hujan antara 2500 hingga $3500 \mathrm{~mm} /$ tahun (Rachim dan Mahfud, 2011).

Tanah podsolik memiliki sifat yang sangat masam $\mathrm{pH} \mathrm{H}_{2}$ Onya mencapai 3,5-5,0, zat organik pada tanah podsolik sedang sampai tinggi, kejenuhan basanya juga rendah, kejenuhan basanya mencapah $30 \%$. Kandungan unsur hara dalam tanah podsolik ini juga sangat rendah (Rachim dan Mahfud, 2011).

Lahan yang digunakan pada penelitian ini adalah lahan podsolik yang terletak di Desa Hawang Kecamatan Limpasu Kabupaten Hulu Sungai Tengah. Uji laboratorium telah dilakukan pada lahan ini yang menunjukkan bahwa kandungan $\mathrm{N}$ total $1,146 \%$ atau rendah, kandungan $\mathrm{P}$ total $28,909 \%$ atau sangat tinggi, kandungan $\mathrm{K}$ total 0,902 atau rendah, kandungan $\mathrm{pH} \mathrm{H}_{2} \mathrm{O}$ 4,42 atau sangat masam, kandungan $\mathrm{C}$ organik 14,974 atau sangat tinggi, kandungan Mg 2,093 atau sedang dan kandungan $\mathrm{Ca}$ 1,166 atau sangat rendah (Balittra, 2018).

Kandungan unsur hara, tekstur tanah, banyaknya mineral liat, dan penurunan kandungan air pada tanah podsolik menyebabkan tanah ini tidak subur, sehingga salah satu pengelolaan pada tanah podsolik dengan menambahkan bahan organik (pemupukan). Dengan penambahan bahan organik maka granulasi terbentuk dan tanah menjadi remah dan porositas total meningkat (Indrayatie, 2009).

Pupuk adalah unsur-unsur esensial baik makro maupun mikro, baik dalam bentuk komponen anorganik maupun organik yang dibutuhkan oleh tanaman untuk kelangsungan hidupnya. Pupuk organik adalah pupuk yang diproses dari limbah organik seperti kotoran hewan, sampah, sisa tanaman, serbuk gergaji kayu, lumpur aktif, yang kualitasnya tergantung dari proses yang diberikan. Pertanian organik adalah suatu sistem produksi yang menghindari penggunaan pupuk-pupuk sintetik, pestisida, pengatur pertumbuhan dan bahan-bahan aditif pakan ternak (Yulipriyanto, 2010).

Pupuk organik memiliki sifat-sifat yang baik terhadap kesuburan tanah antara lain bahan-bahan organik dalam proses mineralisasi akan melepas hara tanaman yang lengkap seperti N, P, K, Ca, Mg, S, serta hara mikro dalam jumlah tidak tentu dan relatif kecil. Bahan organik dapat memperbaiki struktur tanah, menyebabkan tanah menjadi ringan untuk diolah dan mudah ditembus akar. Bahan organik dapat mempermudah pengolahan tanah-tanah yang berat. Bahan organik meningkatkan daya menahan air, sehingga kemampuan tanah untuk memyediakan air menjadi lebih banyak setra kelengasan air tanah lebih terjaga. Bahan organik membuat permeabilitas tanah menjadi lebih baik, menurunkan permeabilitas pada tanah bertekstur kasar dan meningkatkan permeabilitas pada tanah bertekstur sangat lembut. Bahan organik meningkatkan kapasitas pertukaran kation sehingga kemampuan mengikat kation menjadi lebih tinggi. Akibatnya, jika tanah yang dipupuk dengan bahan organik dengan dosis tinggi hara tanaman tidak mudah tercuci (Rosmarkam dan Nasih, 2017).

Guano merupakan pupuk organik yang memiliki bahan efektif untuk penyubur tanah karena kandungan fosfor dan nitrogennya tinggi. Superfosfat yang terbuat dari guano digunakan untuk topdressing. Tanah yang kekurangan zat organik dapat dibuat lebih produktif dengan tambahan pupuk ini. Guano mengandung amonia, asam urat, asam fosfat, asam oksalat, dan asam 
karbonat, serta garam tanah. Tingginya kandungan nitrat juga menjadikan guano komoditas strategis. Kandungan nutrisi pupuk organik guano adalah sebutan dari tumpukan alami kotoran padat dan urine dari kelelawar atau burung-burung laut yang dikumpulkan dari goa-goa tempat populasi hewan tersebut tinggal dan berkembang biak. Guano merupakan sumber pupuk organik atau pupuk alami yang baik untuk budidaya tanaman buah, sayur-sayuran dan berbagai tanaman pangan lainnya (Samudro, 2016).

Menurut Hasan (2011), pemanfaatan guano kotoran kelelawar untuk tanaman terong ungu pada lahan rawa lebak mendapatkan hasil tanaman terong ungu yang tertinggi diperoleh pada perlakuan pemberian guano kotoran kelelawar $5 \mathrm{t}$. ha ${ }^{-1}$ $(0,55 \mathrm{~kg}$. petak), sedangkan pada hasil terendah didapatkan pada perlakuan pemberian guano kotoran kelelawar 20 t. ha 1 .

Menurut Mulyono et. al. (2013), pemanfaatan guano kotoran walet untuk budidaya tanaman bawang merah diperoleh hasil tanaman bawang merah yang tertinggi pada perlakuan pemberian guano kotoran walet $10 \mathrm{t}$. ha ${ }^{-1}$, sedangkan hasil tanaman bawang merah yang terendah pada perlakuan pemberian guano kotoran walet 5 t. ha ${ }^{-1}$.

Berdasarkan berbagai kendala yang telah diuraikan di atas maka perlunya dilaksanakan penelitian tentang aplikasi berbagai dosis dan dua jenis guano pada budidaya tanaman jagung pakan (Zea mays L.) di lahan podsolik.

Tujuan Penelitian ini adalah (i) untuk mengetahui pengaruh interaksi berbagai dosis dan dua jenis guano pada budidaya tanaman jagung pakan di lahan podsolik (ii) mengetahui pengaruh berbagai dosis guano pada budidaya tanaman jagung pakan di lahan podsolik (iii) mengetahui pengaruh dua jenis guano pada budidaya tanaman jagung pakan di lahan podsolik (iv) mendapatkan interaksi terbaik antara berbagai dosis dan dua jenis guano pada budidaya tanaman jagung pakan di lahan podsolik (v) mendapatkan dosis terbaik guano pada budidaya tanaman jagung pakan di lahan podsolik (vi) mendapatkan jenis guano terbaik pada budidaya tanaman jagung pakan di lahan podsolik.

\section{METODE PENELITIAN}

Penelitian ini dilaksanakan di Desa Hawang RT. 001 RW. 001 Kecamatan Limpasu Kabupaten Hulu Sungai Tengah di lahan podsolik dari bulan Maret sampai dengan Juni 2018. Bahan yang digunakan adalah Benih jagung, lahan, guano kotoran kekelawar, guano kotoran walet, pestisida, air dan plang penelitian. Alat yang digunakan adalah Tugal, cangkul, sekop, parang, gembor, ember, hand sprayer, alat tulis, kamera, meteran dan timbangan. Penelitian ini menggunakan Rancangan Acak Kelompok (RAK) dimana pengelompokan dilakukan berdasarkan topografi lahan, sedangkan 2 faktor sebagai perlakuan adalah: (i) berbagai dosis guano (D) terdiri dari 5 taraf yaitu: (1) $\mathrm{d}_{1}=5 \mathrm{t}$. ha ${ }^{-1}$ setara dengan 1,5 kg. petak $^{-1},(2) d_{2}=10$ t. ha ${ }^{-1}$ setara dengan 3 kg. petak ${ }^{-1},(3) d_{3}=15 \mathrm{t}^{-}$ha $^{-1}$ setara dengan 4,5 kg. petak ${ }^{-1}$, (4) $\mathrm{d}_{4}=20 \mathrm{t}$. ha ${ }^{-1}$ setara dengan $6 \mathrm{~kg}$. petak ${ }^{-1}$ dan (5) $\mathrm{d}_{5}=25 \mathrm{t} \mathrm{ha}^{-1}$ setara dengan $7,5 \mathrm{~kg}$. petak $^{-1}$. (ii) dua jenis guano $(\mathrm{G})$ terdiri dari 2 taraf yaitu: (1) $\mathrm{g}_{1}=$ Guano kotoran kelelawar dan (2) $g_{2}=$ Guano kotoran walet. Keseluruhan percobaan sebanyak 10 kombinasi perlakuan dan diulang sebanyak 3 kelompok, sehingga didapatkan 30 satuan percobaan. Setiap satuan percobaan terdiri dari 16 tanaman dan 4 tanaman sampel.

\section{HASIL DAN PEMBAHASAN}

Hasil
Tinggi Tanaman
Berdasarkan hasil analisis ragam
diketahui bahwa interaksi antara berbagai
dosis dan dua jenis guano tidak berpengaruh,
sedangkan perlakuan tunggal berbagai dosis
guano dan perlakuan tunggal dua jenis guano
berpengaruh nyata terhadap tinggi tanaman
jagung pakan. Hasil uji rata-rata tinggi
tanaman jagung pakan pada perlakuan dosis
disajikan pada Tabel 1.


pada perlakuan berbagai dosis

\begin{tabular}{ccccc}
\hline \multirow{2}{*}{ Perlakuan } & \multicolumn{4}{c}{ Rata-rata tinggi tanaman $(\mathrm{cm})$} \\
\cline { 2 - 5 } & $14 \mathrm{HST}$ & $28 \mathrm{HST}$ & $42 \mathrm{HST}$ & $56 \mathrm{HST}$ \\
\hline $\mathrm{d}_{1}$ & $15,88^{\mathrm{a}}$ & $44,37^{\mathrm{a}}$ & $121,04^{\mathrm{a}}$ & $216,21^{\mathrm{a}}$ \\
$\mathrm{d}_{2}$ & $16,54^{\mathrm{b}}$ & $47,33^{\mathrm{b}}$ & $123,83^{\mathrm{b}}$ & $218,87^{\mathrm{b}}$ \\
$\mathrm{d}_{3}$ & $17,75^{\mathrm{c}}$ & $48,92^{\mathrm{c}}$ & $134,62^{\mathrm{c}}$ & $222,33^{\mathrm{c}}$ \\
$\mathrm{d}_{4}$ & $18,08^{\mathrm{d}}$ & $50,46^{\mathrm{d}}$ & $144,00^{\mathrm{d}}$ & $226,67^{\mathrm{d}}$ \\
$\mathrm{d}_{5}$ & $19,25^{\mathrm{e}}$ & $55,17^{\mathrm{e}}$ & $161,18^{\mathrm{e}}$ & $230,37^{\mathrm{e}}$ \\
\hline
\end{tabular}

Keterangan: Nilai rata-rata yang diikuti oleh huruf yang sama pada kolom yang sama menunjukkan perlakuan tersebut tidak berbeda berdasarkan DMRT pada taraf $5 \%$

Dari Tabel 1 terlihat bahwa pada umur 14 HST perlakuan $\mathrm{d}_{5}$ menunjukkan tinggi tanaman paling tinggi yaitu $19,25 \mathrm{~cm}$ yang berbeda dengan perlakuan $\mathrm{d}_{4}, \mathrm{~d}_{3}, \mathrm{~d}_{2}$ dan $\mathrm{d}_{1}$. Pada umur 28 HST perlakuan $\mathrm{d}_{5}$ menunjukkan tinggi tanaman paling tinggi yaitu 55,17 $\mathrm{cm}$ yang berbeda dengan perlakuan $\mathrm{d}_{4}, \mathrm{~d}_{3}, \mathrm{~d}_{2}$ dan $\mathrm{d}_{1}$. Pada umur 42 HST perlakuan $d_{5}$ menunjukkan tinggi tanaman paling tinggi yaitu $161,18 \mathrm{~cm}$ berbeda dengan perlakuan $\mathrm{d}_{4}, \mathrm{~d}_{3}, \mathrm{~d}_{2}$ dan $\mathrm{d}_{1}$. Pada perlakuan 56 HST perlakuan $\mathrm{d}_{5}$ menunjukkan tinggi tanaman paling tinggi yaitu 230,37 $\mathrm{cm}$ berbeda dengan perlakuan $\mathrm{d}_{4}, \mathrm{~d}_{3}, \mathrm{~d}_{2}$ dan $\mathrm{d}_{1}$.

\section{Jumlah Daun}

Berdasarkan hasil analisis ragam diketahui bahwa interaksi antara berbagai dosis dan dua jenis guano tidak berpengaruh, perlakuan tunggal dua jenis guano juga tidak berpengaruh. Sedangkan perlakuan tunggal berbagai dosis guano berpengaruh nyata terhadap jumlah daun tanaman jagung pakan. Hasil uji rata-rata jumlah daun pada perlakuan dosis guano dapat dilihat pada Tabel 2.

Tabel 2. Hasil uji rata-rata jumlah daun jagung pakan umur 14, 28, 42 dan 56 HST pada perlakuan dosis guano

\begin{tabular}{ccccc}
\hline \multirow{2}{*}{ Perlakuan } & \multicolumn{4}{c}{ Rata-rata jumlah daun (helai) } \\
\cline { 2 - 5 } & 14 HST & 28 HST & 42 HST & 56 HST \\
\hline $\mathrm{d}_{1}$ & $5,87^{\mathrm{a}}$ & $9,25^{\mathrm{a}}$ & $9,87^{\mathrm{a}}$ & $11,29^{\mathrm{a}}$ \\
$\mathrm{d}_{2}$ & $6,46^{\mathrm{b}}$ & $10,21^{\mathrm{b}}$ & $10,67^{\mathrm{b}}$ & $11,62^{\mathrm{a}}$ \\
$\mathrm{d}_{3}$ & $6,42^{\mathrm{b}}$ & $10,37^{\mathrm{b}}$ & $11,79^{\mathrm{c}}$ & $12,17^{\mathrm{b}}$ \\
$\mathrm{d}_{4}$ & $6,79^{\mathrm{b}}$ & $11,00^{\mathrm{c}}$ & $11,96^{\mathrm{c}}$ & $12,75^{\mathrm{b}}$ \\
$\mathrm{d}_{5}$ & $6,87^{\mathrm{b}}$ & $11,50^{\mathrm{c}}$ & $13,75^{\mathrm{d}}$ & $13,92^{\mathrm{c}}$ \\
\hline
\end{tabular}

Keterangan : Nilai rata-rata yang diikuti oleh huruf yang sama pada kolom yang sama menunjukkan perlakuan tersebut tidak berbeda berdasarkan DMRT pada taraf $5 \%$

Dari Tabel 2 terlihat bahwa pada umur 14 HST perlakuan $\mathrm{d}_{5}$ menunjukkan jumlah daun tanaman paling banyak yaitu 6,87 helai yang tidak berbeda dengan perlakuan $\mathrm{d}_{4}, \mathrm{~d}_{3}, \mathrm{~d}_{2}$ namun berbeda dengan $\mathrm{d}_{1}$. Pada umur 28 HST perlakuan $\mathrm{d}_{5}$ menunjukkan daun tanaman paling banyak yaitu 11,50 helai yang berbeda dengan perlakuan $\mathrm{d}_{4}, \mathrm{~d}_{3}, \mathrm{~d}_{2}$ dan $\mathrm{d}_{1}$. Pada umur 42 HST perlakuan $\mathrm{d}_{5}$ menunjukkan jumlah daun tanaman paling banyak yaitu 13,75 helai berbeda dengan perlakuan $d_{4}, d_{3}, d_{2}$ dan $d_{1}$. Pada perlakuan 56 HST perlakuan $\mathrm{d}_{5}$ menunjukkan jumlah daun tanaman paling banyak yaitu 13,92 helai berbeda dengan perlakuan $\mathrm{d}_{4}, \mathrm{~d}_{3}, \mathrm{~d}_{2}$ dan $\mathrm{d}_{1}$.

\section{Umur Berbunga}

Berdasarkan hasil analisis ragam diketahui bahwa interaksi antara berbagai dosis dan 
dua jenis guano tidak berpengaruh, perlakuan tunggal dua jenis guano juga tidak berpengaruh, sedangkan perlakuan berbagai dosis guano terhadap umur berbunga tanaman jagung pakan berpengaruh sangat nyata. Hasil uji rata-rata umur berbunga tanaman jagung pakan pada perlakuan berbagai dosis guano disajikan pada Tabel 3 .

Tabel 3. Hasil uji rata-rata umur berbunga tanaman jagung pakan pada perlakuan berbagai dosis guano

\begin{tabular}{cc}
\hline Perlakuan & Umur berbunga (hari) \\
\hline $\mathrm{d}_{1}$ & $49,00^{\mathrm{c}}$ \\
$\mathrm{d}_{2}$ & $48,50^{\mathrm{b}}$ \\
$\mathrm{d}_{3}$ & $48,33^{\mathrm{b}}$ \\
$\mathrm{d}_{4}$ & $48,00^{\mathrm{b}}$ \\
$\mathrm{d}_{5}$ & $47,27^{\mathrm{a}}$ \\
\hline
\end{tabular}

Keterangan : Nilai rata-rata yang diikuti oleh huruf yang sama pada kolom yang sama menunjukkan perlakuan tersebut tidak berbeda berdasarkan DMRT pada taraf 5\%

Dari Tabel 5 terlihat bahwa pada perlakuan $\mathrm{d}_{5}$ menunjukkan umur berbunga paling cepat yaitu 47,27 hari yang berbeda dengan perlakuan $d_{4}, d_{3}, d_{2}$, dan $d_{1}$.

\section{Umur Panen}

Berdasarkan hasil analisis ragam diketahui bahwa interaksi antara berbagai dosis dan dua jenis guano tidak berpengaruh, perlakuan tunggal dua jenis guano juga tidak berpengaruh. Sedangkan perlakuan tunggal berbagai dosis guano terhadap umur panen tanaman jagung pakan berpengaruh sangat nyata. Hasil uji rata-rata umur panen tanaman jagung pakan pada perlakuan berbagai dosis guano disajikan pada Tabel 4 .

Tabel 4. Hasil uji rata-rata umur panen tanaman jagung pakan pada perlakuan berbagai dosis jenis guano

\begin{tabular}{cc}
\hline Perlakuan & Umur panen (hari) \\
\hline $\mathrm{d}_{1}$ & $104,29^{\mathrm{c}}$ \\
$\mathrm{d}_{2}$ & $104,04^{\mathrm{c}}$ \\
$\mathrm{d}_{3}$ & $101,12^{\mathrm{b}}$ \\
$\mathrm{d}_{4}$ & $100,50^{\mathrm{a}}$ \\
$\mathrm{d}_{5}$ & $100,21^{\mathrm{a}}$ \\
\hline
\end{tabular}

Keterangan : Nilai rata-rata yang diikuti oleh huruf yang sama pada kolom yang sama menunjukkan perlakuan tersebut tidak berbeda berdasarkan DMRT pada taraf 5\%

Dari Tabel 4 terlihat bahwa pada perlakuan $\mathrm{d}_{5}$ menunjukkan umur panen paling cepat yaitu 100,21 hari yang berbeda dengan perlakuan $\mathrm{d}_{4}, \mathrm{~d}_{3}, \mathrm{~d}_{2}$, dan $\mathrm{d}_{1}$.

\section{Panjang tongkol berkelobot}

Berdasarkan hasil analisis ragam diketahui bahwa interaksi antara berbagai dosis dan dua jenis guano terhadap panjang tongkol berkelobot tanaman jagung pakan berpengaruh nyata, perlakuan tunggal berbagai dosis guano juga berpengaruh sangat nyata. Sedangkan perlakuan tunggal dua jenis guano tidak berpengaruh. Hasil uji rata-rata panjang tongkol berkelobot tanaman jagung pakan pada perlakuan berbagai dosis guano disajikan pada Tabel 5.

Tabel 5. Hasil uji rata-rata panjang tongkol berkelobot tanaman jagung pakan pada 
berbagai dosis guano serta interaksi berbagai dosis dan dua jenis guano

\begin{tabular}{cccc}
\hline Perlakuan & \multicolumn{2}{c}{ Jenis guano $(\mathrm{G})$} & Rata-rata $(\mathrm{D})$ \\
\hline Dosis guano $(\mathrm{D})$ & $\mathrm{g}_{1}$ & $\mathrm{~g}_{2}$ & \\
\hline $\mathrm{d}_{1}$ & $22,16^{\mathrm{a}}$ & $22,67^{\mathrm{b}}$ & $22,41^{\mathrm{a}}$ \\
$\mathrm{d}_{2}$ & $25,00^{\mathrm{d}}$ & $22,42^{\mathrm{b}}$ & $23,71^{\mathrm{b}}$ \\
$\mathrm{d}_{3}$ & $23,17^{\mathrm{c}}$ & $27,50^{\mathrm{e}}$ & $25,33^{\mathrm{c}}$ \\
$\mathrm{d}_{4}$ & $28,75^{\mathrm{f}}$ & $29,75^{\mathrm{g}}$ & $29,25^{\mathrm{d}}$ \\
$\mathrm{d}_{5}$ & $33,67^{\mathrm{i}}$ & $31,42^{\mathrm{h}}$ & $32,54^{\mathrm{e}}$ \\
Rata-rata $(\mathrm{G})$ & 26,35 & 26,75 & \\
\hline
\end{tabular}

Keterangan: Nilai rata-rata yang diikuti oleh huruf yang sama pada kolom yang sama menunjukkan perlakuan tersebut tidak berbeda berdasarkan DMRT pada taraf 5\%

Dari Tabel 5 terlihat bahwa guano kotoran kelelawar $\left(\mathrm{g}_{1}\right)$ dengan dosis $7,5 \mathrm{~kg}$. petak $^{-1}\left(\mathrm{~d}_{5}\right)$ dengan menunjukkan panjang tongkol berkelobot paling panjang yaitu $33,67 \mathrm{~cm}$ yang berbeda dengan $\mathrm{d}_{4}, \mathrm{~d}_{3}, \mathrm{~d}_{2}$ dan $\mathrm{d}_{1}$, sedangkan guano kotoran walet $\left(\mathrm{g}_{2}\right)$ dengan dosis $7,5 \mathrm{~kg}$. $\operatorname{petak}^{-1}\left(\mathrm{~d}_{5}\right)$ menunjukkan panjang tongkol berkelobot paling panjang yaitu $31,42 \mathrm{~cm}$ yang berbeda dengan $d_{4}, d_{3}, d_{2}$ dan $d_{1}$.

\section{Panjang tongkol tanpa kelobot}

Tabel 6. Hasil uji rata-rata panjang tongkol tanpa kelobot tanaman jagung pakan pada perlakuan berbagai dosis guano

\begin{tabular}{cc}
\hline Perlakuan & Panjang tongkol tanpa kelobot $(\mathrm{cm})$ \\
\hline $\mathrm{d}_{1}$ & $15,87^{\mathrm{a}}$ \\
$\mathrm{d}_{2}$ & $16,62^{\mathrm{a}}$ \\
$\mathrm{d}_{3}$ & $17,71^{\mathrm{b}}$ \\
$\mathrm{d}_{4}$ & $18,96^{\mathrm{c}}$ \\
$\mathrm{d}_{5}$ & $20,92^{\mathrm{e}}$ \\
\hline
\end{tabular}

Keterangan : Nilai rata-rata yang diikuti oleh huruf yang sama pada kolom yang sama menunjukkan perlakuan tersebut tidak berbeda berdasarkan DMRT paada taraf $5 \%$

Dari Tabel 6 terlihat bahwa pada dosis 7,5 kg. petak $^{-1}\left(\mathrm{~d}_{5}\right)$ menunjukkan panjang tongkol tanpa kelobot paling panjang yaitu $20,92 \mathrm{~cm}$ yang berbeda dengan $\mathrm{d}_{4}, \mathrm{~d}_{3}$, $\mathrm{d}_{2}$ dan $\mathrm{d}_{1}$.

\section{Bobot tongkol berkelobot}

Berdasarkan hasil analisis ragam diketahui bahwa interaksi antara berbagai
Berdasarkan hasil analisis ragam diketahui bahwa interaksi antara berbagai dosis dan dua jenis guano terhadap panjang tongkol tanpa kelobot tanaman jagung pakan tidak berpengaruh, perlakuan tunggal dua jenis guano juga tidak berpengaruh. Sedangkan perlakuan tunggal berbagai dosis guano berpengaruh sangat nyata. Hasil uji rata-rata panjang tongkol tanpa kelobot tanaman jagung pakan pada perlakuan berbagai dosis guano disajikan pada Tabel 6 .

Tabel 7. Hasil uji rata-rata bobot tongkol berkelobot tanaman jagung pakan pada

dosis dan dua jenis guano terhadap bobot tongkol berkelobot tanaman jagung pakan tidak berpengaruh, perlakuan tunggal dua jenis guano juga tidak berpengaruh. Sedangkan perlakuan tunggal berbagai dosis guano berpengaruh sangat nyata. Hasil uji rata-rata bobot tongkol berkelobot tanaman jagung pakan pada perlakuan berbagai dosis guano disajikan pada Tabel 7.

\section{perlakuan berbagai dosis guano}




\begin{tabular}{cc}
\hline Pelakuan & Bobot tongkol berkelobot $(\mathrm{g})$ \\
\hline $\mathrm{d}_{1}$ & $248,92^{\mathrm{a}}$ \\
$\mathrm{d}_{2}$ & $282,37^{\mathrm{b}}$ \\
$\mathrm{d}_{3}$ & $299,75^{\mathrm{c}}$ \\
$\mathrm{d}_{4}$ & $337,04^{\mathrm{d}}$ \\
$\mathrm{d}_{5}$ & $404,75^{\mathrm{e}}$ \\
\hline
\end{tabular}

Keterangan : Nilai rata-rata yang diikuti oleh huruf yang sama pada kolom yang sama menunjukkan perlakuan tersebut tidak berbeda berdasarkan DMRT pada taraf $5 \%$

Dari Tabel 7 terlihat bahwa pada dosis 7,5 kg. petak ${ }^{-1}\left(\mathrm{~d}_{5}\right)$ menunjukkan bobot tongkol berkelobot paling berat yaitu 404,75 g yang berbeda dengan $\mathrm{d}_{4}, \mathrm{~d}_{3}, \mathrm{~d}_{2}$ dan $\mathrm{d}_{1}$.

\section{Bobot tongkol tanpa kelobot}

Berdasarkan hasil analisis ragam diketahui bahwa interaksi antara berbagai dosis dan dua jenis guano terhadap bobot tongkol tanpa kelobot tanaman jagung pakan tidak berpengaruh, perlakuan tunggal dua jenis guano juga tidak berpengaruh. Sedangkan perlakuan tunggal berbagai dosis guano berpengaruh sangat nyata. Hasil uji rata-rata bobot tongkol tanpa kelobot tanaman jagung pakan pada perlakuan berbagai dosis guano disajikan pada Tabel 8 .

Tabel 8. Hasil uji rata-rata bobot tongkol tanpa kelobot tanaman jagung pakan pada perlakuan berbagai dosis guano

\begin{tabular}{cc}
\hline Perlakuan & Bobot tongkol tanpa kelobot $(\mathrm{g})$ \\
$\mathrm{d}_{1}$ & $179,08^{\mathrm{a}}$ \\
$\mathrm{d}_{2}$ & $189,20^{\mathrm{b}}$ \\
$\mathrm{d}_{3}$ & $236,00^{\mathrm{c}}$ \\
$\mathrm{d}_{4}$ & $273,25^{\mathrm{d}}$ \\
$\mathrm{d}_{5}$ & $290,08^{\mathrm{e}}$ \\
\hline
\end{tabular}

Keterangan : Nilai rata-rata yang diikuti oleh huruf yang sama pada kolom yang sama menunjukkan perlakuan tersebut tidak berbeda berdasarkan DMRT pada taraf 5\%

Dari Tabel 8 terlihat bahwa pada dosis $7,5 \mathrm{~kg}$. petak $^{-1}\left(\mathrm{~d}_{5}\right)$ menunjukkan bobot tongkol tanpa kelobot paling berat yaitu 290,08 g yang berbeda dengan $d_{4}, d_{3}, d_{2}$ dan $\mathrm{d}_{1}$.

\section{Pembahasan}

\section{Interaksi Berbagai Dosis dan Dua Jenis Guano}

Berdasarkan hasil analisis ragam menunjukkan bahwa interaksi berbagai dosis dan dua jenis guano tidak bepengaruh terhadap semua variabel pengamatan kecuali panjang tongkol berkelobot. Menurut Novizan (2002), pertumbuhan tanaman jagung sangat memerlukan unsur hara $\mathrm{N}$ dalam jumlah yang cukup. Unsur hara $\mathrm{N}$ berguna untuk merangsang pertumbuhan tanaman secara keseluruhan, merangsang pertumbuhan vegetatif dan berfungsi untuk sintesa asam amino dan protein dalam tanaman.

Menurut Novizan (2002), unsur hara $\mathrm{N}$ juga dibutuhkan untuk membentuk senyawa penting seperti klorofil, asam nukleat, dan enzim. Karena itu, unsur hara $\mathrm{N}$ dibutuhkan dalam jumlah besar pada setiap tahap pertumbuhannya, khususnya pada tahap pertumbuhan vegetatif, seperti pembentukan tunas atau perkembangan batang dan daun. Peranan $\mathrm{P}$ dalam pertumbuhan vegetatif tanaman hanya berkisar $0,3-0,5 \%$. $\mathrm{P}$ mempunyai peran 
dalam memperbaiki pertumbuhan akar tanaman, kerapatan akar dapat distimulasi oleh $\mathrm{P}$ meskipun tidak sebaik pengaruh $\mathrm{N}$. Sedangkan peranan $\mathrm{K}$ dalam pertumbuhan vegetatif tanaman adalah untuk memperbaiki transportasi asimilat, menghemat penggunaan air melalui pengaturan membuka-menutupnya stomata dan meningkatkan ketahanan tanaman terhadap serangan hama dan penyakit.

Menurut Sarawa, et. al., (2012), pupuk guano dapat memperbaiki tingkat kesuburan tanah, karena kandungan unsur $\mathrm{N}$, $\mathrm{P}, \mathrm{K}$ dan Ca yang sangat tinggi sehingga baik untuk proses pertumbuhan tanaman. Nitrogen sangat dibutuhkan tanaman untuk mendukung pertumbuhan vegetatif tanaman. Selanjutnya fosfor (P) merangsang pertumbuhan akar dan pembungaan, kalium (K) terutama berperan untuk memperkuat jaringan tanaman terutama batang tanaman, sedangkan $\mathrm{Ca}$ akan mengubah atau menggeser kedudukan ion $\mathrm{H}$ pada permukaan koloid sehingga menetralisir kemasaman tanah. Selain itu $\mathrm{Ca}$ juga sangat penting peranannya dalam mempertahankan permeablitas membran sel.

Pemberian bahan organik dapat meningkatkan kandungan C-organik dan Norganik serta kapasitas tukar kation tanah. Bahan organik yang diberikan ke dalam tanah akan terdekomposisi sehingga meningkatkan C-organik dan Norganik tanah.Tanah yang sifat fisiknya menjadi baik, memberikanketersediaan air dan udara menjadi seimbang yang mengakibatkan pada perakaran tanaman akan tumbuh dan berkembang dengan baik (Nainggolan dan Hapsoh, 2017).

Proses metabolisme tanaman sangat ditentukan oleh ketersediaan hara pada tanaman terutama unsur hara $\mathrm{N}, \mathrm{P}$ dan $\mathrm{K}$ dalam jumlah yang cukup, sedangkan untuk pertumbuhan generatif tanaman membutuhkan unsur $\mathrm{P}$ dan $\mathrm{K}$ yang lebih dominan. Unsur fosfor merupan unsur penyusun sel, lemak protein yang mempercepat pembungaan dan pemasakan buah serta memacu pertumbuhan akar dan unsur kalium yang berperan sebagai katalisator dalam transportasi tepung, gula, dan lemak pada tanaman, meningkatkan kualitas hasil yang berupa bunga dan buah (Nainggolan dan Hapsoh, 2017).

Nitrogen merupakan unsur hara utama bagi pertumbuhan tanaman sebab merupakan penyusun dari semua protein dan asam nukleat serta sebagai penyusun protoplasma secara keseluruhan. Nitrogen diambil tanaman dalam bentuk amonium (NH4+) dan nitrat (NO). Nitrogen yang diambil dalam bentuk nitrat akan tereduksi menjadi amonium melalui enzim yang mengandung molibdenum. Ion-ion amonium dan beberapa karbohidrat mengalami sintesis dalam daun dan diubah menjadi asam amino. Apabila unsur nitrogen yang tersedia lebih banyak dari pada unsur lainnya, dapat dihasilkan protein lebih banyak dan daun dapat tumbuh lebih lebar, sebagai akibatnya maka fotosintesis meningkat (Hayanti et. al., 2014).

Apabila fotosintesis meningkat, maka meningkat pula sintesis karbohidrat. Karbohidrat ini diperlukan dalam pembelahan sel, pembesaran sel dan pembentukan jaringan untuk perkembangan batang, daun dan akar (pertumbuhan vegetatif). Pemberian nitrogen yang tepat akan meningkatkan pertumbuhan tanaman, maka meningkat pula metabolisme tanaman sehingga pembentukan protein, karbohidrat dan pati tidak terhambat. Akibatnya pertumbuhan dan produksi tanaman meningkat (Hayanti et. al., 2014).

\section{Dosis Guano}

Berdasarkan hasil analisis ragam menunjukkan bahwa perlakuan tunggal berbagai dosis berpengaruh terhadap semua variabel pengamatan, pemberian guano karena diduga dalam dosis yang tinggi dapat meningkatkan pertumbuhan tanaman pada lahan podsolik. Pemberian tersebut dapat meningkatkat unsur hara yang tersedia dalam tanah sehingga tanah tersebut akan kaya dengan unsur hara $\mathrm{N}, \mathrm{P}, \mathrm{K}$ dan $\mathrm{C}$ organik. Respon akar terhadap penyerapan unsur hara dalam jumlah yang banyak sangat efektif, karena unsur hara yang diberikan ke dalam tanah mampu berfungsi secara optimal, sehingga pemberian pupuk guano mampu memenuhi kebutuhan hara bagi tanaman 
dalam mendukung pertumbuhan tanaman jagung pakan.

Menurut Nainggolan dan Hapsoh (2017), pemberian bahan organik berupa pupuk kandang dan pupuk hijau meningkatkan kandungan C-organik dan $\mathrm{N}$ organik serta kapasitas tukar kation tanah. Bahan organik yang diberikan ke dalam tanah akan terdekomposisi sehingga meningkatkan C-organik dan Norganik tanah.Tanah yang sifat fisiknya menjadi baik, memberikanketersediaan air dan udara menjadi seimbang yang mengakibatkan pada perakaran tanaman akan tumbuh dan berkembang dengan baik.

Menurut Nainggolan dan Hapsoh (2017), proses metabolisme tanaman sangat ditentukan oleh ketersediaan hara pada tanaman terutama unsur hara $\mathrm{N}, \mathrm{P}$ dan $\mathrm{K}$ dalam jumlah yang cukup, sedangkan untuk pertumbuhan generatif tanaman membutuhkan unsur $\mathrm{P}$ dan $\mathrm{K}$ yang lebih dominan. Unsur fosfor merupan unsur penyusun sel, lemak protein yang mempercepat pembungaan dan pemasakan buah serta memacu pertumbuhan akar dan unsur kalium yang berperan sebagai katalisator dalam transportasi tepung, gula, dan lemak pada tanaman, meningkatkan kualitas hasil yang berupa bunga dan buah.

Menurut Lingga dan Marsono (1991), unsur $\mathrm{N}$ sangat penting untuk pertumbuhan vegetatif tanaman karena dapat merangsang pertumbuhan secara keseluruhan, khususnya batang dan daun. Selama proses pertumbuhan dan perkembangan dari mulai berkecambah sampai menghasilkan buah, tanaman memerlukan berbagai macam unsur hara seperti nitrogen yang dapat meningkatkan pertumbuhan vegetatif akar, batang dan daun tanaman serta memberikan warna hijau pada daun yang berhubungan dengan klorofil dalam peranannya pada proses fotosintesis, berperan dalam penggunaan posfor dan kalium pada suatu tanaman dan tanaman yang kekurangan unsur hara $\mathrm{N}$ akan tumbuh kerdil dan sistem perakaran terhambat. Unsur $\mathrm{N}$ sangat penting dalam proses vegetatif tanaman, pada awal pertumbuhan tanaman bagian yang pertama tumbuh dan berkembang adalah bagian daun, batang dan akar.
Menurut

Sutedjo

(2010), pertumbuhan tanaman membutuhkan banyak unsur $\mathrm{N}$. Unsur $\mathrm{N}$ berguna untuk merangsang pertumbuhan tanaman secara keseluruhan, merangsang pertumbuhan vegetative dan berfungsi untuk sintesa asam amino dan protein dalam tanaman. Nitrogen juga dibutuhkan untuk membentuk senyawa penting seperti klorofil, asam nukleat dan enzim. Tanaman akan dapat tumbuh dan berproduksi dengan sempurna apabila unsur hara yang diperlukan cukup. Unsur N, P dan $\mathrm{K}$ merupakan unsur hara yang sangat dibutuhkan tanaman pada awal pertumbuhan terutama pada tinggi tanaman.

Menurut Mahdiannoor et. al. (2016), unsur hara $\mathrm{P}$ sangat mempengaruhi pembentukan tongkol. P dapat memperbesar pembentukan buah, selain itu ketersediaan $\mathrm{P}$ sebagai pembentuk ATP akan menjamin ketersediaan energi bagi pertumbuhan sehingga pembentukan asimilat dan pengangkutan ke tempat penyimpanan dapat berjalan dengan baik. Hal ini menyebabkan tongkol yang dihasilkan berdiameter besar. Pembesaran diameter tongkol berhubungan dengan ketersediaan unsur P. Bila unsur P pada tanaman jagung terpenuhi maka pembentukan tongkol jagung akan lebih sempurna dengan ukuran yang lebih besar dan barisan bijinya penuh.

Menurut Gardner et. al. (1991), unsur $\mathrm{K}$ penting untuk produksi dan penyimpanan karbohidrat, sehingga tanaman yang menghasilkan karbohidrat dalam jumlah tinggi mempunyai kebutuhan kalium yang tinggi. Uunsur hara mempengaruhi bobot tongkol terutama biji, karena hara yang diserap oleh tanaman akan dipergunakan untuk pembentukan protein, karbohidrat, dan lemak yang nantinya akan disimpan dalam biji sehingga akan meningkatkan bobot tongkol.

\section{Jenis Guano}

Berdasarkan analisis ragam jenis guano yang berpengaruh adalah guano kotoran kelelawar $\left(\mathrm{g}_{1}\right)$, pemberian dua jenis pupuk guano berpengaruh nyata terhadap pertumbuhan tinggi tanaman pada umur 56 HST. Diduga karena pada umur 56 HST pupuk guano sudah terurai maksimal, 
sedangkan pada pertumbuhan jumlah daun, umur berbunga, umur panen, panjang tongkol berkelobot, panjang tongkol tanpa kelobot, bobot tongkol berkelobot dan bobot tanpa kelobot tidak berpengaruh. Menurut Hariyadi (2015), guano walet bersifat lambat larut atau melepaskan unsur hara secara perlahan, maka interval waktu pemberian dimaksudkan untuk menjamin ketersediaan hara yang cukup pada saat diperlukan, sehingga ketersediaan hara tersebut dapat bersinergi dengan umur dan pertumbuhan. Pupuk organik guano belum sepenuhnya terurai dalam tanah yang tersusun dari materi mahluk hidup, seperti pelapukan sisa-sisa tanaman dan hewan. Pupuk organik dapat berbentuk padat atau cair yang dipergunakan untuk memperbaiki sifat fisik, kimia, dan biologi tanah.

Menurut Hayanti et. al. (2014), kandungan unsur hara kompos kotoran kelelawar N, P, K termasuk dalam kategori sangat tinggi. Hal ini karena adanya proses dekomposisi senyawa-senyawa yang terkandung dalam kotoran kelelawar, jerami padi, arang sekam dan dedak seperti gula, pati, protein, selulosa, lignin dan lemak didegradasi menjadi senyawa carbon (C), hidrogen $(\mathrm{H})$, oksigen $(\mathrm{O})$, abu dan unsurunsur mineral. Selain itu protein juga didegradasi menjadi amida dan asam amino sedangkan lemak menjadi gliserida dan asam lemak.

Menurut Hayanti et. al. (2014), penggunaan kompos kotoran kelelawar (guano) berpengaruh terhadap pertumbuhan vegetatif tanaman kacang tanah pada parameter berat basah tanaman, tinggi tanaman dan panjang akar tanaman serta berpengaruh terhadap pertumbuhan generatif/produksi tanaman kacang tanah pada parameter jumlah ginofor, jumlah polong dan berat polong tanaman kacang tanah. Pemberian bahan organik meningkatkan pertumbuhan tanaman kacang tanah, hal ini karena mineralisasi bahan organik melepaskan unsur hara makro dan mikro sehingga ketersediaan hara dalam tanah meningkat. Peningkatan ketersediaan hara akan berpengaruh terhadap peningkatan serapan hara sehingga proses pertumbuhan juga meningkat.
Pemberian bahan organik juga dapat menciptakan kondisi lingkungan yang sesuai untuk tanaman dengan memperbaiki aerasi, mempermudah penetrasi akar, memperbaiki kapasitas menahan air, meningkatkan $\mathrm{pH}$, kapasitas tukar kation (KTK), serapan hara serta struktur tanah menjadi remah. Bahan organik dapat meningkatkan kesuburan tanah, biomassa, dan produksi tanaman pangan (Sarawa, et. al., 2012).

Salah satu bahan organik yang dapat digunakan untuk meningkatkan produktivitas tanah adalah pupuk guano. Pupuk guano dapat memperbaiki tingkat kesuburan tanah, karena kandungan unsur $\mathrm{N}, \mathrm{P}, \mathrm{K}$ dan Ca yang sangat tinggi sehingga baik untuk proses pertumbuhan tanaman. Nitrogen sangat dibutuhkan tanaman untuk mendukung pertumbuhan vegetatif tanaman. Selanjutnya fosfor $(\mathrm{P})$ merangsang pertumbuhan akar dan pembungaan, kalium $(\mathrm{K})$ terutama berperan untuk memperkuat jaringan tanaman terutama batang tanaman, sedangkan Ca akan mengubah atau menggeser kedudukan ion $\mathrm{H}$ pada permukaan koloid sehingga menetralisir kemasaman tanah. Selain itu Ca juga sangat penting peranannya dalam mempertahankan permeablitas membran sel (Sarawa, et. al., 2012).

\section{KESIMPULAN}

Interaksi berbagai dosis dan dua jenis guano pada budidaya tanaman jagung pakan di lahan podsolik berpengaruh terhadap panjang bobot berkelobot; perlakuan berbagai dosis guano pada budidaya tanaman jagung pakan di lahan podsolik berpengaruh nyata terhadap semua variabel pengamatan; perlakuan dua jenis guano pada budidaya tanaman jagung pakan di lahan podsolik berpengaruh pada pertumbuhan tinggi tanaman jagung pakan; tidak ada interaksi terbaik terhadap berbagai dosis dan dua jenis guano pada budidaya tanaman jagung pakan; didapatkan dosis terbaik guano yaitu $\mathrm{d}_{5}\left(7,5 \mathrm{~kg}\right.$. petak $\left.^{-1}\right)$ pada budidaya tanaman jagung pakan di lahan podsolik dan didapatkan jenis guano terbaik yaitu g (guano kotoran kelelawar) pada budidaya tanaman jagung pakan di lahan podsolik 


\section{DAFTAR PUSTAKA}

Balittra. 2018. Hasil Analisis Tanah dan Pupuk. Balittra. Banjarbaru.

Direktorat Jenderal Hortikultura. 2017. Produksi Jagung Pakan di Indonesia. Direktorat Jenderal Hortikultura. Jakarta.

Gardner, F. P, R. B. Pearce dan R. L. Mitchell. 1991. Fisiologi Tanaman Budidaya. Universitas Indonesia. Jakarta.

Hariyadi. 2015. Respon Tanaman Mentimun (Cucumis sativus L.) terhadap Pemberian Pupuk Kandang Kotoran Ayam dan Guano Walet pada Tanah Gambut Pedalaman. Volume 12 dan Nomor 01. http:/fmipa.unlam.ac.id. Diakses Pada tanggal 22 Oktober 2018.

Hasan, F. 2011, Respon Pertumbuhan dan Hasil Tanaman Terung Ungu (Solanum melongena L.) terhadap Pemberian Dosis Pupuk Guano pada Lahan Rawa Lebak. Skripsi. STIPER Amuntai. Amuntai.

Hayanti, E. D. N., Yuliani dan Herlina, F. 2014. Penggunaan kompos kotoran kelelawar (guano) untuk meningkatkan pertumbuhan tanaman kacang tanah (Arachis hypogaea). Jurnal Lentera Biologi. Volume 03 dan Nomor 01. Universitas Negeri Surabaya. Surabaya.

Indrayatie, E. R. 2009. Distribusi pori tanah podsolik merah kuning pada berbagai kepadatan tanah dan pemberian bahan organik. Jurnal Hutan Tropis Borneo Volume 10 dan Nomor 27. Universitas Lambung Mangkurat. Banjarbaru.

Lingga, P dan Marsono. 1991. Petunjuk Penggunaan Pupuk. Penebar Swadaya. Jakarta.
Mahdiannoor. Istiqomah, $\mathrm{N}$ dan Syarifuddin. 2016. Aplikasi pupuk organik cair terhadap pertumbuhan dan hasil tanaman jagung manis. Ziraa'ah, Volume 41 dan Nomor 1.

Mulyono, Teti, A. dan Syakur. 2013. Aplikasi pupuk guano dan mulsa organik serta pengaturan jarak tanam untuk meningkatkan kualitas tanah dan hasil tanaman bawang merah (Allium ascalonicum L.). Jurnal Manajemen Sumberdaya Lahan. Volume 03 dan Nomor 01. Fakultas Pertanian Unsyiah. Darussalam Banda Aceh.

Nainggolan, G dan Hapsoh. 2017. Respons tanaman jagung manis (Zea mays saccharata Sturt) yang diberi pupuk guano dengan NPK di lahan gambut. Jurnal Jom Feparta. Volume 04 dan Nomor 02. Universitas Riau. Riau.

Novizan. 2002. Petunjuk Pemupukan yang Efektif. PT. Agromedia Pustaka. Jakarta.

Rachim, D. A dan Mahfud, A. 2011. Klasifikasi Tanah Indonesia. Pustaka Reka Cipta. Bandung.

Rosmarkam, A. dan Nasih, W. Y. 2017. Ilmu Kesuburan Tanah. Kanisius. Yogyakarta.

Samudro. 2016. Kandungan Nutrisi Pupuk Organik Guano. https://organikilo.com. Diakses pada tanggal 27 November 2017.

Sarawa. Andi, R dan Muh, D. A. 2012. Pertumbuhan dan produksi tanaman kedelai (Glycine max L.) yang diberi pupuk guano dan mulsa alang-alang. Jurusan Agroteknolog. Volume 02 dan Nomor 02. Universitas Haluoleo. Kendari.

Sulaeman, Suparto dan Eviati. 2005. Analisis Kimia Tanah, Air, dan Pupuk. Balai Penelitian Tanah Bogor. 
Sutedjo, M. 2010. Pupuk dan Cara

Pemupukan. Rineka Cipta. Jakarta

Yulipriyanto, H. 2010. Biologi Tanah dan Strategi Pengelolaannya. Graha Ilmu. Yogyakarta.
Zubachtirodin, Bambang, S., Mulyono dan Deni, H. 2011. Teknologi Budidaya Jagung. Direktorat Jenderal Tanaman Pangan. Jakarta. 